\title{
ESTIMATED RESERVOIR AGES OF THE BLACK SEA SINCE THE LAST GLACIAL
}

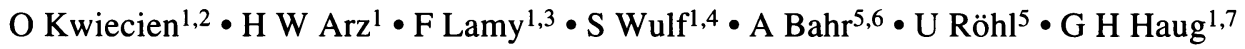

\begin{abstract}
Accelerator mass spectrometry (AMS) radiocarbon dating of ostracod and gastropod shells from the southwestern Black Sea cores combined with tephrochronology provides the basis for studying reservoir age changes in the lateglacial Black Sea. The comparison of our data with records from the northwestern Black Sea shows that an apparent reservoir age of $\sim 1450{ }^{14} \mathrm{C} \mathrm{yr}$ found in the glacial is characteristic of a homogenized water column. This apparent reservoir age is most likely due to the hardwater effect. Though data indicate that a reservoir age of $\sim 1450{ }^{14} \mathrm{C}$ yr may have persisted until the Bølling-Allerød warm period, a comparison with the GISP2 ice-core record suggests a gradual reduction of the reservoir age to $\sim 1000{ }^{14} \mathrm{C} \mathrm{yr}$, which might have been caused by dilution effects of inflowing meltwater. During the Bølling-Allerød warm period, soil development and increased vegetation cover in the catchment area of the Black Sea could have hampered erosion of carbonate bedrock, and hence diminished contamination by "old" carbon brought to the Black Sea basin by rivers. A further reduction of the reservoir age most probably occurred contemporary to the precipitation of inorganic carbonates triggered by increased phytoplankton activity, and was confined to the upper water column. Intensified deep water formation subsequently enhanced the mixing/convection and renewal of intermediate water. During the Younger Dryas, the age of the upper water column was close to $0 \mathrm{yr}$, while the intermediate water was $\sim 900{ }^{14} \mathrm{C} \mathrm{yr}$ older. The first inflow of saline Mediterranean water, at $\sim 8300{ }^{14} \mathrm{C}$ yr BP, shifted the surface water age towards the recent value of $\sim 400{ }^{14} \mathrm{C} \mathrm{yr}$.
\end{abstract}

\section{INTRODUCTION}

One important issue regarding research performed on late-glacial lacustrine sediments of the Black Sea is the lack of a reliable chronostratigraphy. Attempts to decipher the chronology of Quaternary Black Sea deposits are hindered by a lack of material adequate for dating. Rare reports on the reservoir age of the Black Sea provide inconsistent sets of data and consider only marine sediments covering not more than the last $\sim 8000 \mathrm{yr}$ of Black Sea history (e.g. Guichard et al. 1993; Jones and Gagnon 1994). In many aspects, the Black Sea is an exceptional water body. It is the world's largest anoxic basin, having changed in character from freshwater to marine only $8000 \mathrm{yr}$ ago, and is known to have been oscillating between a freshwater and a marine state for at least the last 3 million yr (Schrader 1979). Though lately it gained an increased scientific interest due to the Flood hypothesis (Ryan et al. 1997), little progress has been made in developing consistent age models for its Late Quaternary sediments. The stratigraphy of the longest Black Sea record, so far, core 380A of the DSDP Leg 42, reaches most likely back to Messinian, and was assigned using the freshwater/ marine-brackish flora assemblages, combined with the global sea-level curve (Schrader 1979). In general, Schrader (1979) associated freshwater stages with cold periods (glacial conditions, low global sea-level stand, and no connection to the Mediterranean), while he saw marine-brackish floras as indicative of warm periods (interglacial conditions, high global sea-level stand, open connection to the Mediterranean). Schrader (1979) also found out that transitions from freshwater to marinebrackish (glacial to interglacial) conditions were often followed by sapropel deposits-though not every sapropel marked a freshwater/marine transition. Some sapropels indicated only occasional spills (sudden influxes of marine Mediterranean water).

According to Ross and Degens (1974), late Quaternary ( 25,000 yr) Black Sea sediments are subdivided into the glacial to Holocene lacustrine Unit III (clayey mud) and 2 Holocene marine units: Unit II (finely laminated sapropelic sediments) and Unit I (finely laminated coccolith ooze). The

\footnotetext{
${ }^{1}$ GeoForschungsZentrum Potsdam, Potsdam, Germany.

${ }^{2}$ Corresponding author. Email: kwiecien@gfz-potsdam.de.

${ }^{3}$ Now at the Alfred Wegener Institute for Polar and Marine Research (AWI), Bremerhaven, Germany.

${ }^{4}$ Now at the University of Texas at Austin, Institute for Geophysics, Jackson School of Geosciences, Austin, Texas, USA.

${ }^{5}$ MARUM - Center for Marine Environmental Research, University of Bremen, Bremen, Germany.

${ }^{6}$ IFM-GEOMAR, Kiel, Germany.

${ }^{7}$ Now at the Swiss Federal Institute of Technology (ETH-Zurich), Zurich, Switzerland.
} 
transition from Unit III to Unit II is accompanied by laminated, inorganically precipitated aragonite of variable thickness (from $\mathrm{mm}$ scale to $\sim 10 \mathrm{~cm}$ ). Transitions between the units are stratigraphic markers, which can be correlated on a basin scale. The division into these 3 units, together with the first rough radiocarbon dating, was initially presented by Ross et al. (1970) and later modified by Hay et al. (1990). A depth-increasing discrepancy between the ${ }^{14} \mathrm{C}$ age of organic and carbonate fractions was first observed by Deuser (1972) and later confirmed by Ross and Degens (1974). The dating of the Unit II/III transition (Jones 1991) showed that accelerator mass spectrometry (AMS) ${ }^{14} \mathrm{C}$ dates of organic carbon give consistently younger ages than those of total carbonate. However, the problem of unreliable application of ${ }^{14} \mathrm{C}$ data to construct a consistent chronostratigraphy of the marine units had arisen earlier, with the discovery of a mismatch between the proposed varve chronology and radiometric measurements (Ross and Degens 1974; Degens et al. 1980; Crusius and Anderson 1992). In an attempt to constrain this controversy, Jones and Gagnon (1994) performed a very detailed study of the transitions between Black Sea units, comparing results derived by AMS ${ }^{14} \mathrm{C}$ dating of various materials. Averaging over several dates obtained on carbonates and organic carbon, they calculated $7540 \pm 130 \mathrm{yr}$ BP for the onset of the sapropel formation marking the Unit II/III boundary, $2720 \pm$ $160 \mathrm{yr}$ BP for the first invasion of coccolithophorides marking the Unit I/II boundary, and $1635 \pm 60$ yr BP for the final invasion of coccolithophorides. The recognition of the Z-2 tephra from the Minoan eruption of Santorini dated at $3595 \mathrm{yr}$ BP (Hammer et al. 1987; lately revised to 3577-3550 yr BP, Friedrich et al. 2006), within sediments containing marine organic matter $\sim 1200 \mathrm{yr}$ older than the tephra itself, confirmed and yet underlined the complexity of AMS ${ }^{14} \mathrm{C}$ dating in the marine Black Sea (Guichard et al. 1993). The difficulty of constraining the chronostratigraphy for the lacustrine Black Sea consists in a limitation of available dating methods; carbonate material suitable for ${ }^{14} \mathrm{C}$ dating is commonly very sparse and sediments are either non-laminated or vaguely but not annually laminated. Independent time markers such as, for instance, tephra layers have not been identified so far.

Major et al. (2002) were the first to propose a detailed AMS ${ }^{14} \mathrm{C}$-based chronostratigraphy of lateglacial Black Sea sediments. Dating was performed on adult shells of Dreissena rostriformis from 2 sediment cores recovered at 240 and $378 \mathrm{~m}$ water depth in the northwestern Black Sea (in this study we refer to these depths as to the "upper water column"), and no reservoir correction was applied to the dates obtained. The importance of reservoir corrections due to "too old" ages of glacial Black Sea sediments was noticed by Bahr et al. (2005). Using various carbonate material, they dated 2 cores from a slope transect in the northwestern Black Sea. The stratigraphy based on ostracod and gastropod ${ }^{14} \mathrm{C}$ dates from a core from $1200 \mathrm{~m}$ water depth (Bahr et al. 2005) showed a significant and almost constant offset of $1000{ }^{14} \mathrm{C}$ yr with respect to previously published data based on bivalve ${ }^{14} \mathrm{C}$ dates (Major et al. 2002). On the contrary, oxygen isotope data from the shallower core (168 $\mathrm{m}$ water depth) in the same transect, dated using the same species (articulated shells of D. rostriformis) as in the study published by Major et al. (2002), supported a 0-yr reservoir correction. In conclusion, Bahr et al. (2005) suggested that either the dating samples must have been contaminated by older carbonates or that in the ancient Black Sea basin at least the upper 400 m must have been ventilated, while deeper water masses should have been permanently stratified. This hypothesis, however, is not confirmed by the stable oxygen isotope records coming from the same transect, suggesting that stratification of the Black Sea waters only occurred after $14,500 \mathrm{yr} \mathrm{BP}\left(13,000{ }^{14} \mathrm{C} \mathrm{yr} \mathrm{BP}\right)(\mathrm{Bahr}$ et al. 2006). Interestingly, although the recent Black "Sea" is not exactly an analog for a glacial Black "Lake," measured ages of water from different depths as well as modeled results were not always consistent (e.g. Top and Clarke 1983; Östlund and Dyrssen 1986; Murray et al. 1991). Attempts to assess the reservoir age are listed in Table 1 . Taking advantage of a new ${ }^{14} \mathrm{C}$-dated record from the SW Black Sea, with tephra deposits as independent time markers, we aim to shed light on the late-glacial Black Sea stratigraphy puzzle. Comparing records from different water depths, we propose a potential model of the temporal and spatial evolution of the glacial Black Sea reservoir age. 
O Kwiecien et al.

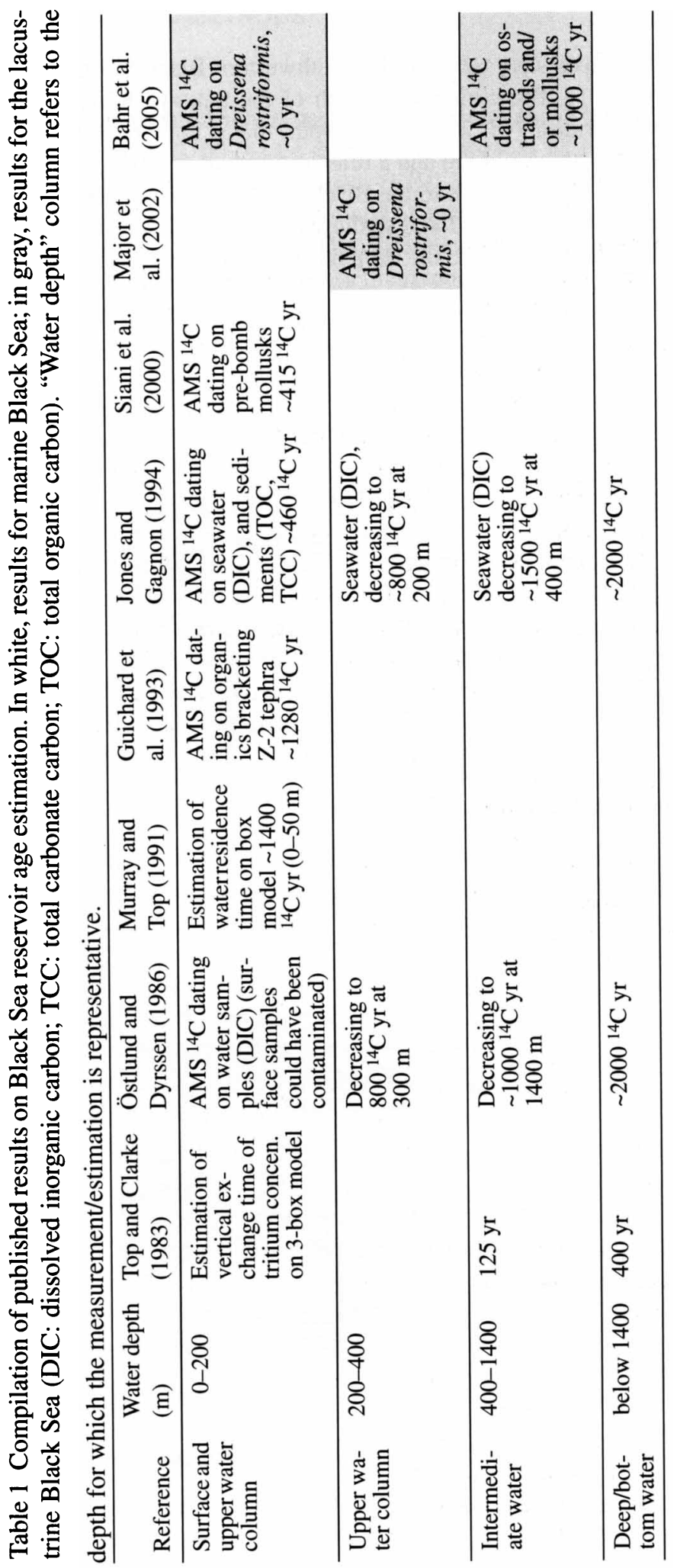




\section{STUDY AREA}

Gravity and piston cores studied in this paper were taken in the southwestern Black Sea from the upper slope off western Anatolia (Figure 1). The coring site, north of the Sakarya River mouth (Table 2), is located on a topographical elevation ( 1220 m water depth) that is not affected by turbidites. The Sakarya River, with a total length of $824 \mathrm{~km}$ and a drainage area of $56,504 \mathrm{~km}^{2}$, is the longest and second largest Anatolian river discharging into the Black Sea (Algan et al. 2002). The southern shelf of the Black Sea, in contrast to the broad and shallow northern one, is very narrow and steep, which results in sediment transport directly to the deep basin. Today, the Coriolis-forcedriven rim current sweeps sediments off the northern shelf and redistributes them to the southwestern slope next to the Anatolian coast (Sur et al. 1996). This, together with the proximal location to the Sakarya River mouth, results in very high sedimentation rates in our study area.

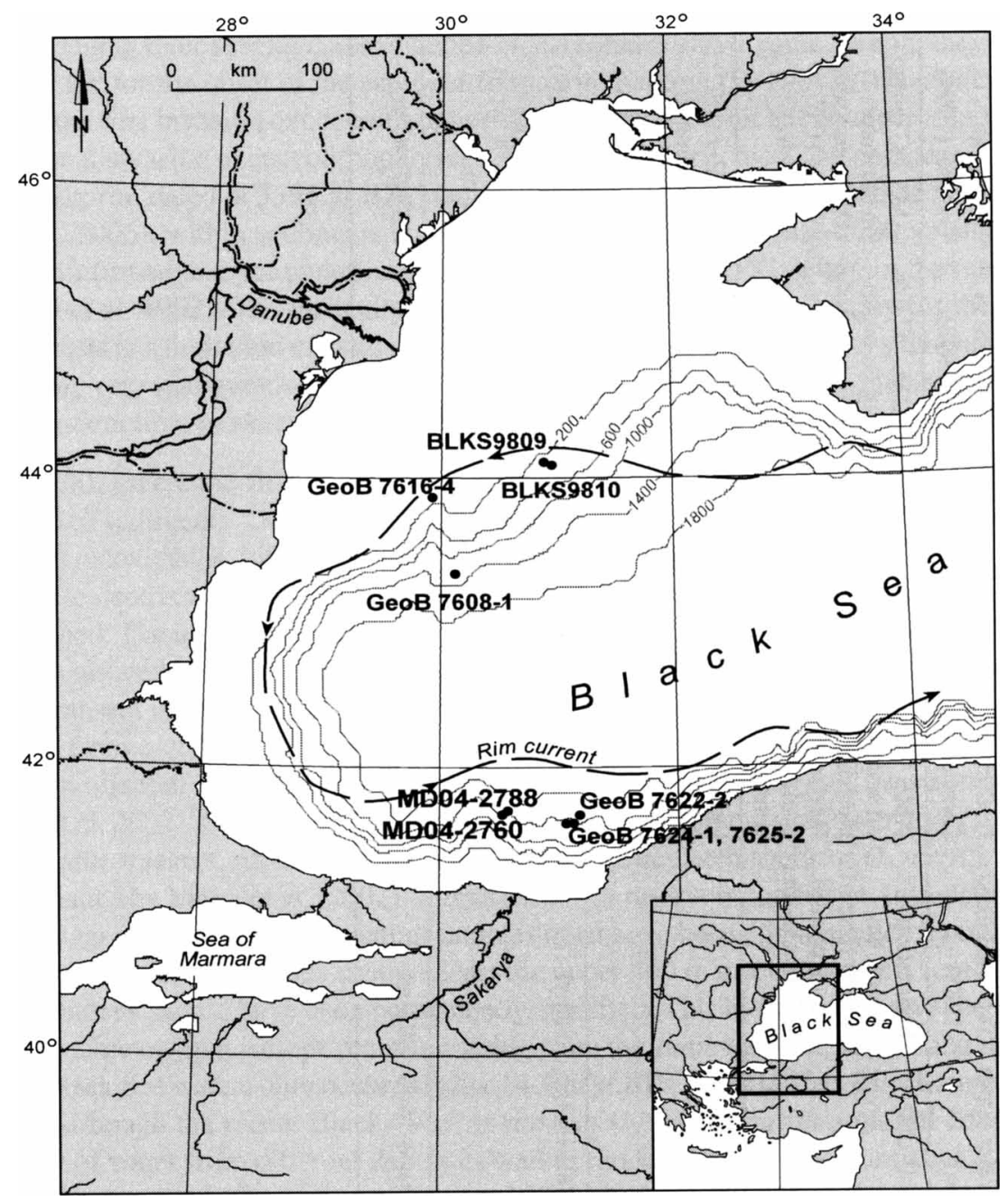

Figure 1 Study area with the locations of sediment cores MD04-2760, MD04-2788, and other cores relevant for this study (GeoB 7622-2, 7624-1, 7625-2 [Lamy et al. 2006]; GeoB 7608-1, GeoB 7616-4 [Bahr et al. 2005]; BLKS9810, BLKS9809 [Major et al. 2002]). The black dashed line indicates the western Black Sea rim current. 


\section{MATERIAL AND METHODS}

\section{Material}

The work presented here is based on the gravity core MD04-2788 $(6 \mathrm{~m})$ and the corresponding piston core MD04-2760 (41.94 m) retrieved at $41^{\circ} 31.67^{\prime} \mathrm{N}, 30^{\circ} 53.09^{\prime} \mathrm{E}$ during the ASSEMBLAGE I cruise onboard the research vessel (R/V) Marion Dufresne in 2004. Both cores reveal the typical marine stratigraphic divisions of units I and II with a combined thickness of 3.23 m for MD04-2788 and $5.91 \mathrm{~m}$ for MD04-2760. The difference found in the thickness of units I and II between the 2 cores is due to differential compaction/elongation within the gravity and piston core. In our case, the elongation factor is on average $2 \times$. The lowermost lacustrine Unit III consists of homogeneous and $\mathrm{cm}$ - to $\mathrm{mm}$-scale laminated muddy clay of $2.67 \mathrm{~m}$ in the gravity core and $24.3 \mathrm{~m}$ in the piston core. The base of Unit III was not reached. The lowermost $11 \mathrm{~m}$ of sediment of the piston core suffered from deformation and bending during the coring procedure and were not used in present study.

\section{Methods}

\section{Profiling Measurements}

After splitting, both cores were scanned at $1 \mathrm{~cm}$ resolution with an AVAATECH X-ray fluorescence (XRF) scanner at the University of Bremen, Germany. Additionally, gravity core MD04-2788 was scanned at $2 \mathrm{~mm}$ resolution. The XRF-core scanner, developed at the Netherlands Institute for Sea Research, Texel, measures the bulk intensities of major elements (e.g. Al, Si, S, K, Ca, Ti, Mn, and $\mathrm{Fe}$ ) on split sediment cores (Jansen et al. 1998). The Ca intensity data obtained were used for correlation with bulk carbonate data and XRF Ca data from previously published records (Major et al. 2002; Bahr et al. 2005).

\section{Tephrochronology}

Two distinct tephra layers have been identified in the sediment cores. One tephra of $0.1 \mathrm{~cm}$ thickness was recognized in the Holocene marine Unit II in both cores MD04-2788 and MD04-2760 at $2.58 \mathrm{~m}$ and $4.4 \mathrm{~m}$ depth, respectively. A similar light-colored tephra was found in gravity cores GeoB 76222, GeoB 7625-2, and GeoB 7624-1 from the southwestern Black Sea at the same stratigraphic position (Lamy et al. 2006), representing the same eruptive event. The second tephra, reddish in color and $0.5 \mathrm{~cm}$ thick, was recognized in the glacial lacustrine part of the piston core MD04-2760 at $26.52 \mathrm{~m}$ depth. The tephra layers in cores GeoB 7622-2, GeoB 7625-2, GeoB 7624-1, and MD042760 were identified by means of major-element electron probe micro-analyses (EPMA). Petrographical and chemical compositions of both tephras were determined using polished thin sections. Sample preparation followed in its entirety that described in detail by Wulf et al. (2002).

\section{Radiocarbon Dating}

AMS ${ }^{14} \mathrm{C}$ dating of lacustrine sediments (Unit III) was performed on shells of either ostracods (mixed samples of Loxoconchidae and Candonidae) or benthic gastropods from the piston core MD04-2760 and on ostracod shells from the gravity core MD04-2788. A total of $14{ }^{14} \mathrm{C}$ samples (Table 3) were measured by AMS at the Leibniz-Labor in Kiel, Germany (Nadeau et al. 1997).

\section{RESULTS}

\section{Composite Profile MD04-2788/2760}

In order to make a core-to-core comparison, we first corrected the original depths of both cores for core gaps. XRF scanning results allowed a detailed correlation of the piston core MD04-2760 and 
the gravity core MD04-2788. Since the uppermost $5.91 \mathrm{~m}$ of the piston core were strongly disturbed (extended) during coring, we substituted the marine part of the MD04-2760 record (units I and II, 0-5.91 m, corrected depth) with the respective part of the undisturbed MD04-2788 record (0$3.23 \mathrm{~m}$, corrected depth). We then normalized the top of the lacustrine unit in the piston core MD042760 to the top of the lacustrine unit in the gravity core MD04-2788 by applying a constant correction of $-2.68 \mathrm{~m}(3.23-5.91=-2.68)$ to each corrected depth value of the lacustrine part of the piston core (original depth, corrected depth, and composite profile depth values are provided in Table 3 ).

\section{Tephrochronology}

On a geochemical, petrographical, and stratigraphical basis, the Holocene tephra was correlated with the marine Z-2 tephra, which has already been found in previous Black Sea sediment records (Guichard et al. 1993; Lamy et al. 2006). This rhyodacitic ash is allocated to the Minoan eruption of Santorini and dates to $3331 \pm 10{ }^{14} \mathrm{C}$ yr BP (3550-3577 cal yr BP; Friedrich et al. 2006) (Figure 2, Table 4).

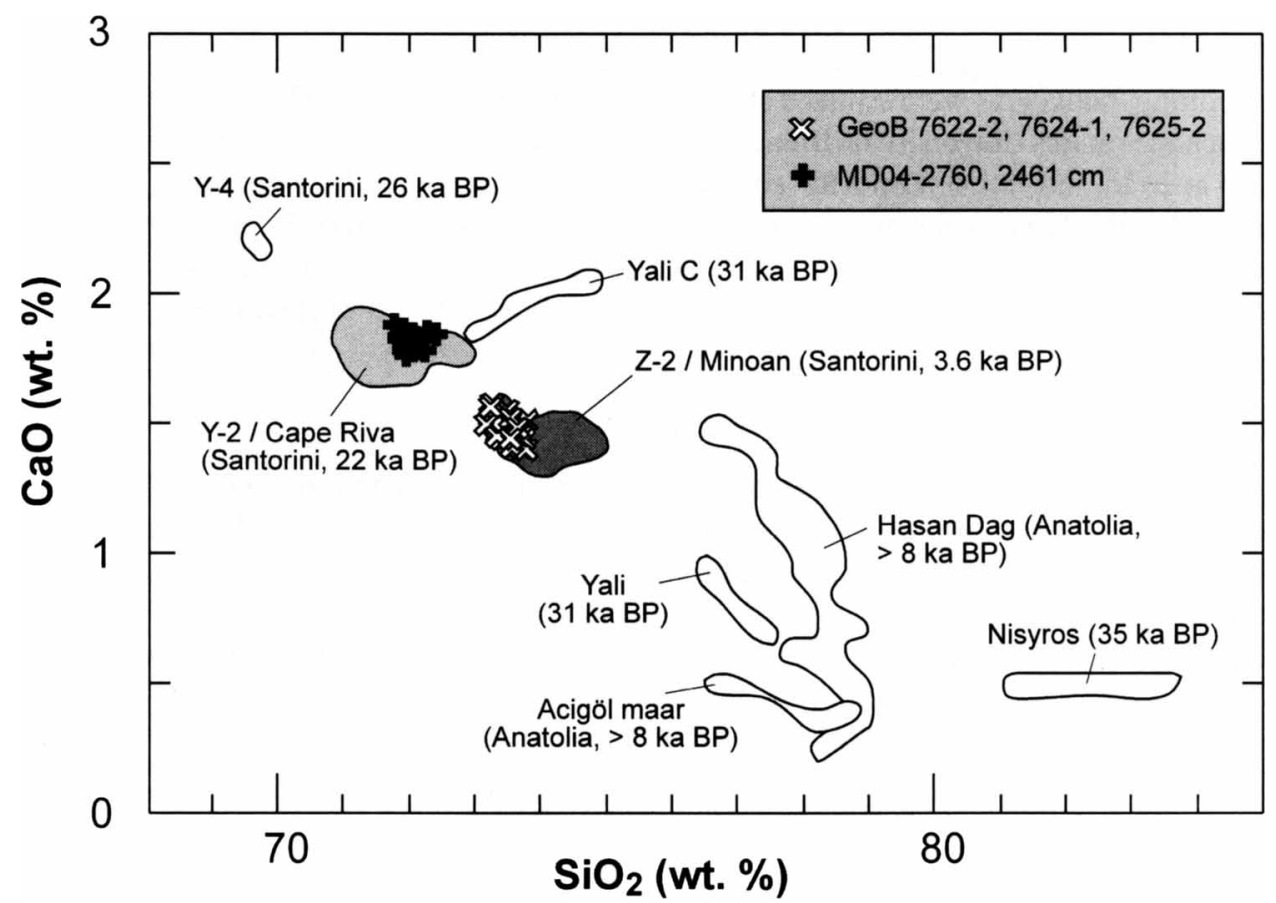

Figure 2 Chemical discrimination of the tephras found in cores GeoB 7622-2, 7624-1, 7625-2, and MD04-2760, and the prominent Quaternary tephra layers from Santorini, Yali, Nisyros, and central Anatolia. Please note that all data are normalized on an anhdrous basis.

The glacial tephra in core MD04-2760 is similarly rhyodacitic in its chemical composition, but corresponds most likely to the late-glacial marine Y-2 tephra. Y-2 has been detected in numerous deepsea cores of the Aegean Sea, the Levantine Basin (e.g. Keller et al. 1978; Federman and Carey 1980; Vinci 1985), and the Sea of Marmara (Wulf et al. 2002), and correlates with the Cape Riva eruption of the Santorini volcano (Figure 2, Table 4; for more details on discrimination of tephras in the Mediterranean region see Vinci [1985] and Wulf et al. [2002, forthcoming] and references therein). Dating of Cape Riva deposits on land (dating wood intercalated with tephra deposits) provided a series 
of $4{ }^{14} \mathrm{C}$ dates: $18,050 \pm 340 ; 18,165 \pm 210 ; 18,880 \pm 230 \mathrm{yr}$ BP (Pichler and Friedrich 1976); and $18,150 \pm 200 \mathrm{yr}$ BP (Eriksen et al. 1990). For further calculations, we applied an age of 18,310 \pm 380 ${ }^{14} \mathrm{C}$ yr BP $(21,270-22,290 \mathrm{cal}$ yr BP $)$ for the tephra representing the mean value and standard deviation obtained from the 4 dates.

\section{Chronology}

A ${ }^{14} \mathrm{C}$-based age model was constrained for the composite profile including both gravity core MD04-2788, for the marine part, and piston core MD04-2760, for the lacustrine part of the record. In order to improve the age model, we further used the Z-2 tephra time marker and additional age points from the recently dated and nearby core GeoB 7622-2 (Lamy et al. 2006) (Figure 1 and Tables 2, 3). All ${ }^{14} \mathrm{C}$ ages determined on core $\mathrm{GeoB} 7622-2$ could be exactly transferred to core MD04-2760 by careful visual inspection of the lamination pattern. Moreover, a comparison with the GeoB 7622-2 record revealed that the uppermost $\sim 64 \mathrm{~cm}$ of our record (extrapolated on the basis of sedimentation rate), covering the last $\sim 1000 \mathrm{yr}$, were lost during the coring procedure (Figure 3 ). We performed a linear interpolation between the age-control points imported from GeoB 7622-1, the ${ }^{14} \mathrm{C}$ age of the Z-2 Minoan Ash obtained from terrestrial deposits (Friedrich et al. 2006), and the age control points from the lacustrine part (consisting of 13 dates derived from the MD04-2760, and 1 date transferred from MD04-2788) (Figure 4a). Since the linear interpolation of the Y-2 tephra age derived an age $1450{ }^{14} \mathrm{C}$ yr older than a mean value of the original dating series (Pichler and Friedrich 1976; Eriksen et al. 1990), this tephra was not directly included in the ${ }^{14} \mathrm{C}$ age model (see discussion below). Only after applying a reservoir correction to the AMS ${ }^{14} \mathrm{C}$ dating results (see below), the mean calibrated age of Y-2 tephra was included in the calibrated age model (Figure 4b). Calibrated ages were calculated with $1-\sigma$ standard deviation. In 2 cases, when 2 dates were available from the same interval (ostracods and gastropods, from 3.63-3.83 $\mathrm{m}$ and 24.97-25.17 m composite depth; Table 3), we used a mean value for constraining the age model. Considering the relatively large volume of sample material required for each dating due to the extremely high sedimentation rates, and therefore dilution of the benthic in situ material, these ages were in good agreement given their dating uncertainties.

Table 2 Location and length of sampled cores.

\begin{tabular}{|c|c|c|c|c|}
\hline Core & Latitude N & Longitude E & $\begin{array}{l}\text { Water depth } \\
\text { (m) }\end{array}$ & $\begin{array}{l}\text { Core length } \\
\text { (m) }\end{array}$ \\
\hline MD04 2760a & $41^{\circ} 31.67^{\prime}$ & $30^{\circ} 53.09^{\prime}$ & 1226 & 41.94 \\
\hline MD04 2788a & $41^{\circ} 31.67^{\prime}$ & $30^{\circ} 53.00^{\prime}$ & 1224 & 6.00 \\
\hline GeoB 7622-2b & $41^{\circ} 32.10^{\prime}$ & $31^{\circ} 10.00^{\prime}$ & 1306 & 7.68 \\
\hline GeoB 7624-1 ${ }^{b}$ & $41^{\circ} 30.00^{\prime}$ & $31^{\circ} 05.10^{\prime}$ & 1370 & 8.75 \\
\hline GeoB 7625-2b & $41^{\circ} 26.70^{\prime}$ & $31^{\circ} 04.00^{\prime}$ & 1242 & 7.92 \\
\hline GeoB $7608-1^{c}$ & $43^{\circ} 29.20^{\prime}$ & $30^{\circ} 11.08^{\prime}$ & 1202 & 6.85 \\
\hline GeoB 7616-4 ${ }^{c}$ & $43^{\circ} 41.00^{\prime}$ & $30^{\circ} 02.50^{\prime}$ & 168 & 9.16 \\
\hline BLSK9809d & $44^{\circ} 05.23^{\prime}$ & $30^{\circ} 47.98^{\prime}$ & 240 & 8.40 \\
\hline BLSK9810 & $44^{\circ} 04.04^{\prime}$ & $30^{\circ} 50.68^{\prime}$ & 378 & 7.59 \\
\hline
\end{tabular}

aThis study.

bLamy et al. 2006.

'Bahr et al. 2005.

dMajor et al. 2002. 


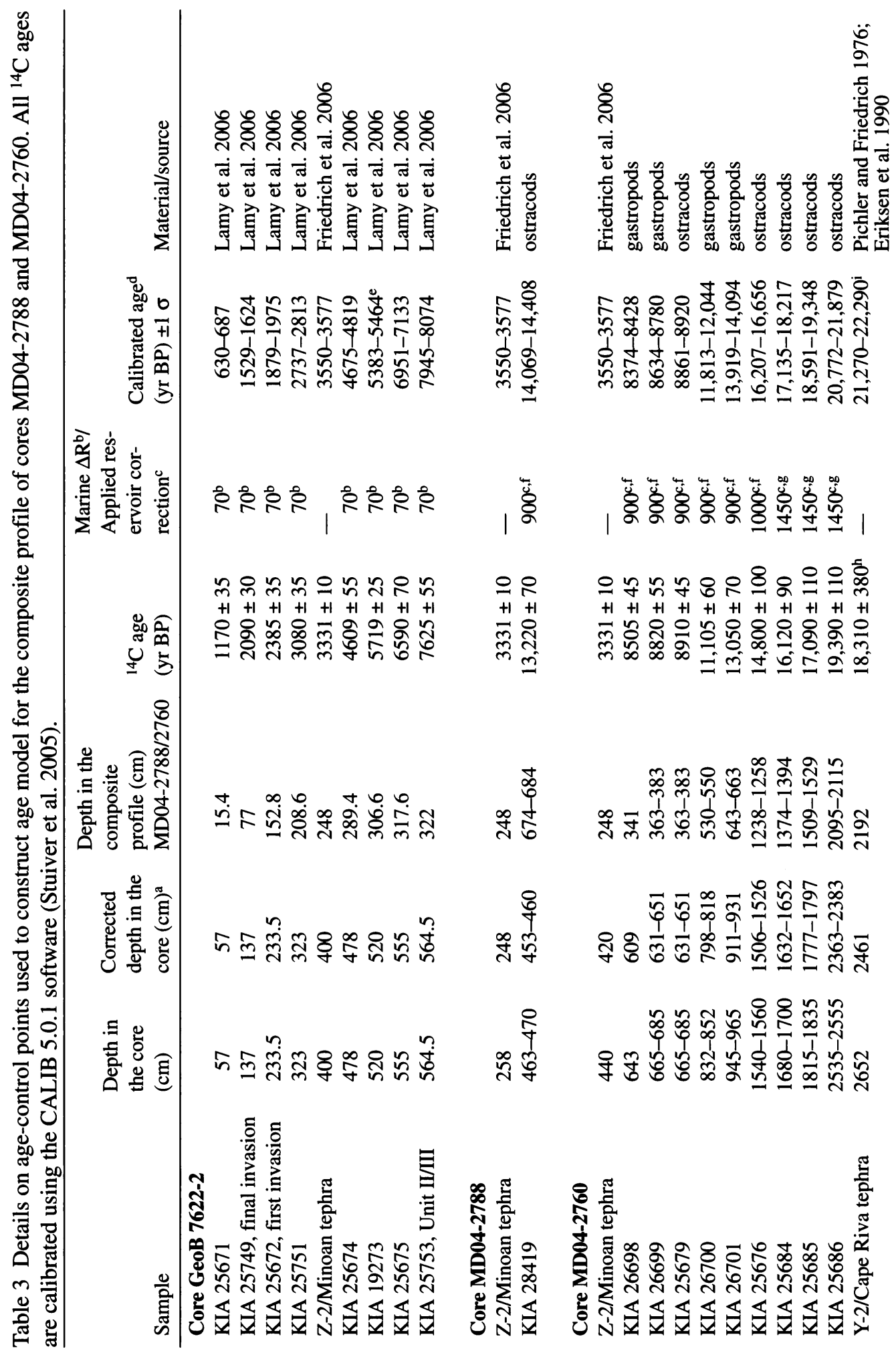




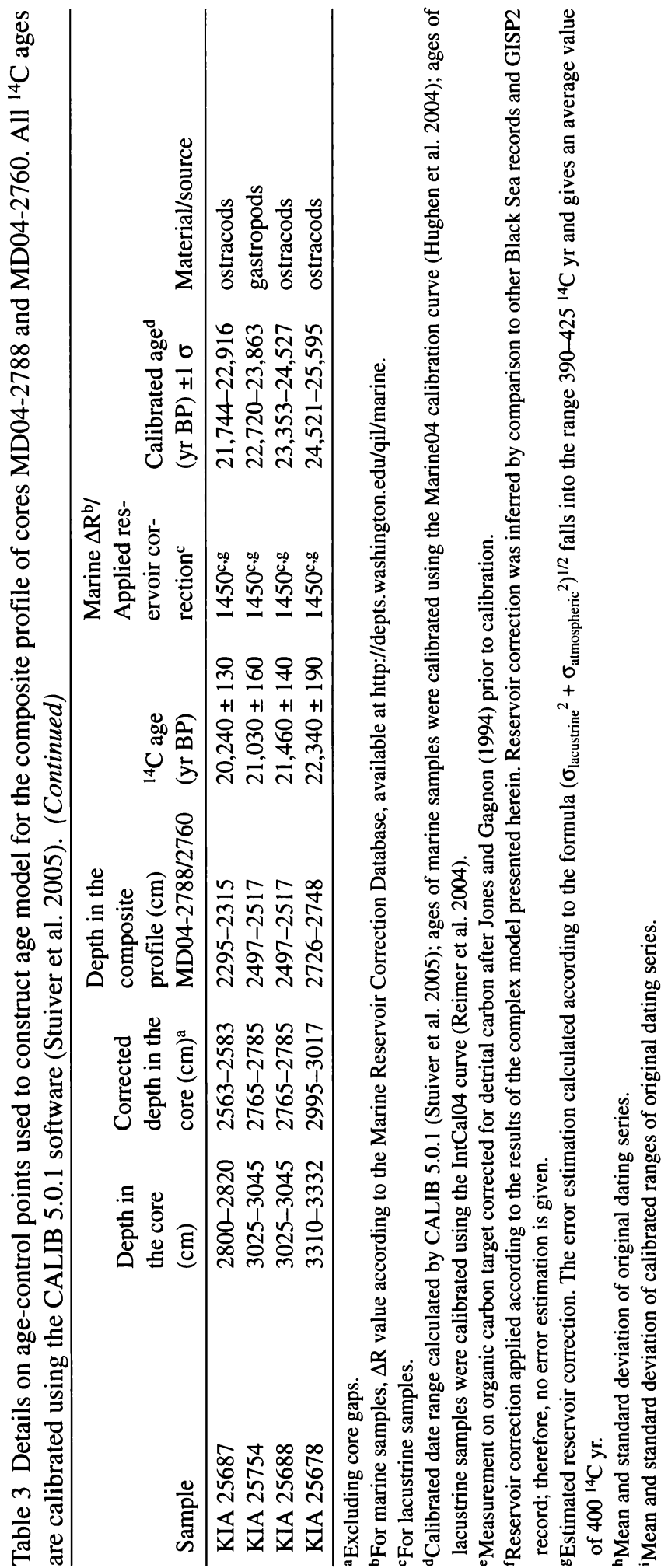




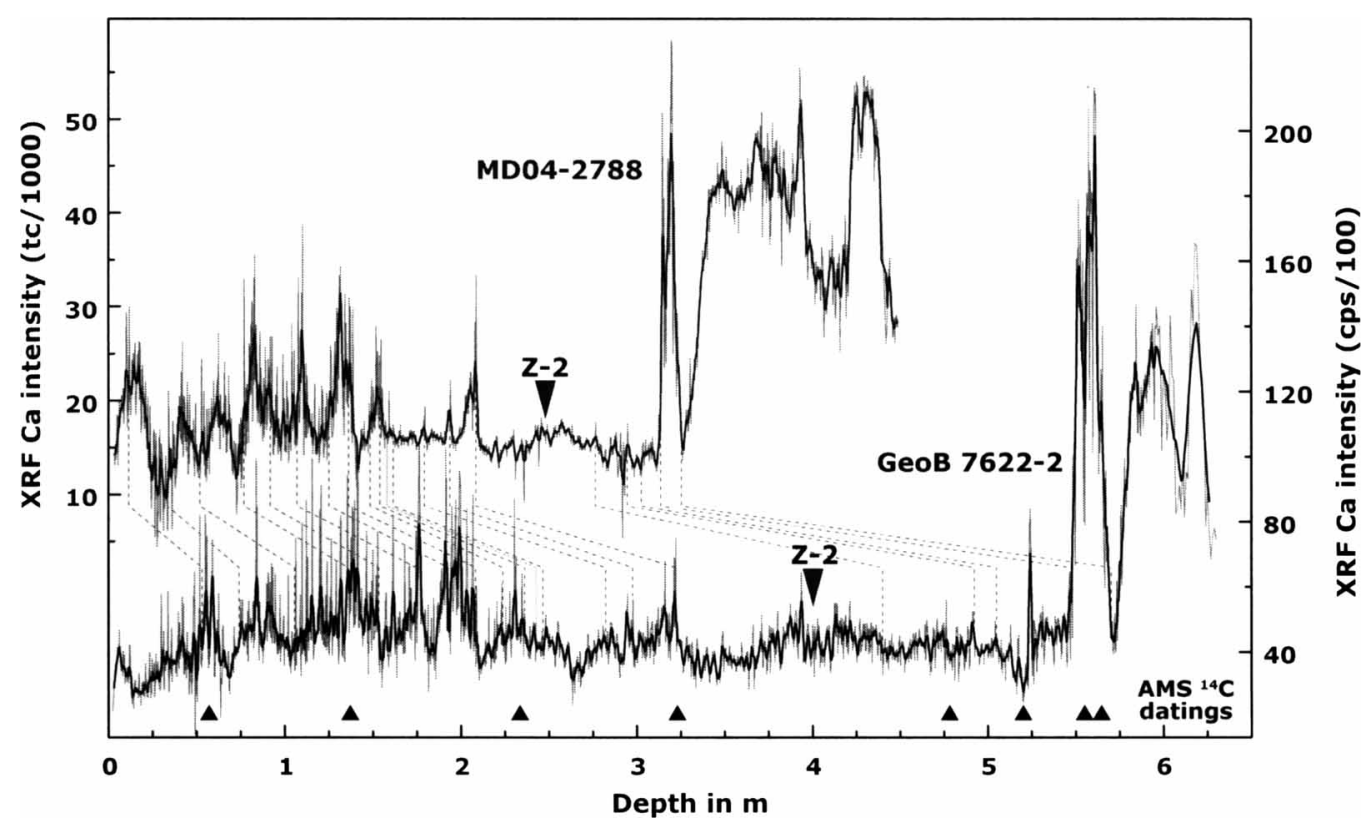

Figure 3 XRF Ca intensity record and dating points from core GeoB 7622-2 (Lamy et al. 2006). The XRF Ca record from MD04-2788 displays a very similar pattern. The dashed lines represent correlation levels, thin lines the original data, and bold lines the 9-point moving average. The 2 cores were measured using different XRF core scanners providing counts per second (cps) for the GeoB 7622-2 and total counts (tc) for the MD04-2788. Accordingly, the values for the $\mathrm{Ca}$ intensity differ in orders of magnitude. AMS ${ }^{14} \mathrm{C}$ dating (indicated by black triangles) was performed on the core GeoB 7622-2.
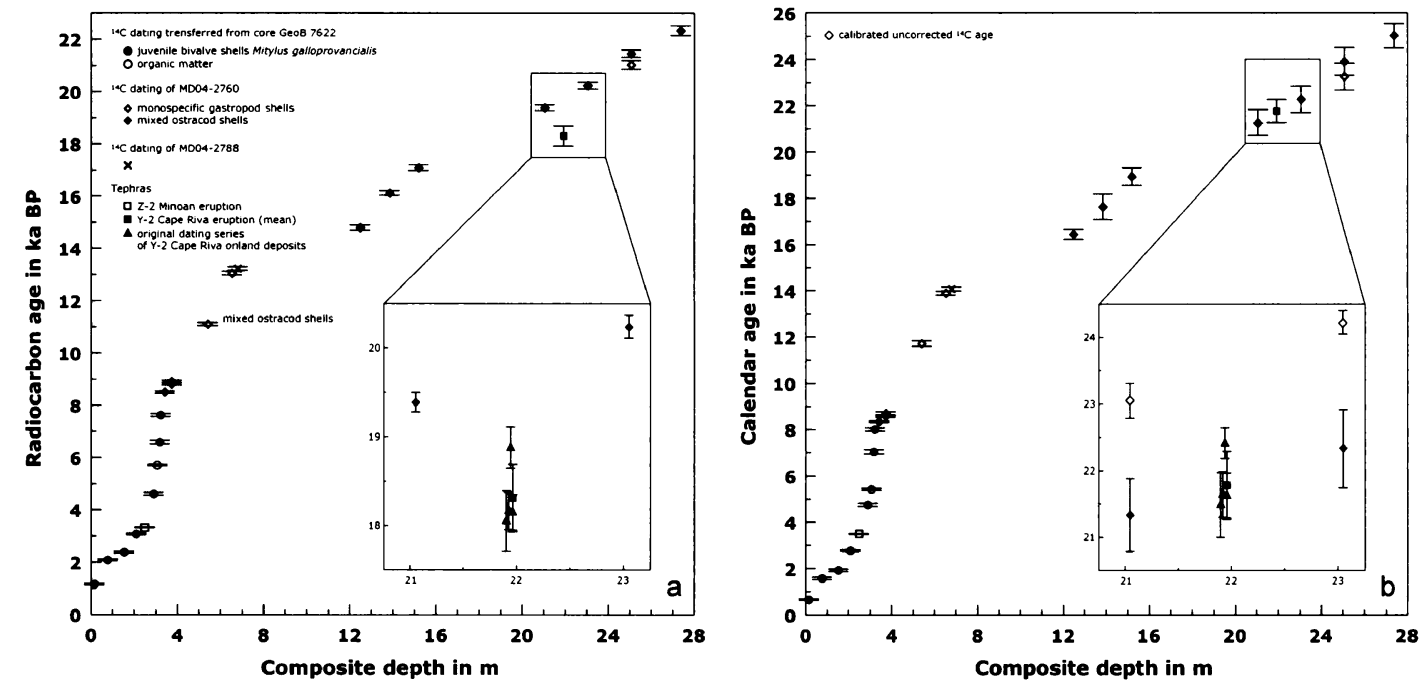

Figure 4 Age-depth model of the composite profile. a) ${ }^{14} \mathrm{C}$ age vs. the composite depth. The zoom-in box shows the original dating series of the Y-2 Cape Riva tephra onland deposits (Pichler and Friedrich 1976; Eriksen et al. 1990) located between 2 bracketing samples of core MD04-2760. b) Calendar age (with 1- $\sigma$ standard deviation) vs. composite depth. Reservoir corrections (for comparison check Table 3) were applied to all ages prior to calibration. The zoom-in box shows the calibrated results of Pichler and Friedrich (1976) and Eriksen et al. (1990). The calibrated uncorrected ages of the 2 samples bracketing the Y-2 tephra are shown for comparison. Because of the relatively big sample volumes required for each dating, the dating results should be viewed as a time frame not for a certain depth point but for a certain depth range. 
Table 4 Mean values of major element chemistry obtained by microprobe analyses on single glass shards from respective tephra deposits. Numbers in parentheses represent the $1-\sigma$ standard deviation and $n=$ number of glass shards analyzed.

\begin{tabular}{lcc}
\hline Sample & GeoB 7622-2, 400 cm & MD04-2760, 2461 cm \\
\hline Event & Minoan (Santorini) & Cape Riva (Santorini) \\
\hline $\mathrm{SiO}_{2}$ & $72.05(0.70)$ & $71.30(0.59)$ \\
$\mathrm{TiO}_{2}$ & $0.29(0.03)$ & $0.48(0.03)$ \\
$\mathrm{Al}_{2} \mathrm{O}_{3}$ & $13.43(0.18)$ & $14.24(0.17)$ \\
$\mathrm{FeO}$ & $2.03(0.06)$ & $3.15(0.12)$ \\
$\mathrm{MnO}$ & $0.07(0.04)$ & $0.12(0.03)$ \\
$\mathrm{MgO}$ & $0.30(0.01)$ & $0.43(0.04)$ \\
$\mathrm{CaO}$ & $1.45(0.04)$ & $1.80(0.03)$ \\
$\mathrm{Na}_{2} \mathrm{O}$ & $4.91(0.10)$ & $4.34(0.24)$ \\
$\mathrm{K}_{2} \mathrm{O}$ & $3.17(0.09)$ & $2.82(0.07)$ \\
$\mathrm{P}_{2} \mathrm{O}_{5}$ & $0.04(0.04)$ & $0.09(0.02)$ \\
$\mathrm{Cl}$ & $0.30(0.02)$ & $0.26(0.02)$ \\
$\mathrm{F}$ & $0.00(0.00)$ & $0.00(0.00)$ \\
Total & $\mathbf{9 7 . 9 9}(\boldsymbol{n}=14)$ & $\mathbf{9 8 . 9 7}(\boldsymbol{n}=\mathbf{1 3})$ \\
\hline
\end{tabular}

\section{Sedimentology}

XRF data obtained on composite core MD04-2788/2760 give a time resolution ranging from 3 to 17 yr. The Ca signal reflects a basin-wide sedimentation pattern and is comparable with a lower-resolution XRF Ca record from the NW Black Sea (Bahr et al. 2005, core GeoB 7608-1) and a low-resolution record of $\mathrm{CaCO}_{3}$ content from bulk carbonates (Major et al. 2002, core BLKS9810) (Figure 5).

The last glacial period is characterized by relatively stable and low $\mathrm{Ca}$ values, which are interrupted at $14,800{ }^{14} \mathrm{C}$ yr BP by a series of Ca minima reflecting a change in the input sources. This interruption is known as the "red layer interval" and was previously interpreted as the result of an outflow of the Caspian Sea into the Black Sea via the Manych depression, caused by increased glacial meltwater discharge (Major et al. 2002; Bahr et al. 2005 and references therein). Alternatively, the deposition of the "red layers" could be generally related to enhanced erosion associated with late-glacial permafrost thawing (Major et al. 2002). The "red layers," also described as brown muds (Major et al. 2002), are enriched in terrigenous components embedded in a silty to clayish matrix. The timing of the red layers in our record is in disagreement with dates proposed by Bahr et al. (2005, GeoB 7608-1) (Figure 5). However, some results of Bahr et al. (2005) could have been biased by dating material containing older, reworked shells. Notably, when tuned to the MD04-2760 XRF Ca intensity record, the XRF Ca signal from core GeoB 7608-1 reveals congruent patterns (Figure 6).

Two distinct $\mathrm{Ca}$ maxima, the carbonate peaks $\mathrm{C} 2$ and $\mathrm{C} 1$ occurring at $13,000-12,000{ }^{14} \mathrm{C}$ yr BP and $10,800-9000{ }^{14} \mathrm{C}$ yr BP, respectively, reflect high amounts of inorganically precipitated calcite (Figure 5, nomenclature for the peaks $\mathrm{C} 2$ and $\mathrm{C} 1$ after Major et al. [2002]; for comparison see Bahr et al. [2005, 2006]). The Ca minimum in between $\mathrm{C} 2$ and $\mathrm{C} 1\left(12,000-11,000{ }^{14} \mathrm{C}\right.$ yr BP) represents reduced carbonate precipitation combined with an increase in terrigenous supply. The youngest $\mathrm{Ca}$ maximum A, located in the core MD04-2788/2760 between 7770 and $6380{ }^{14} \mathrm{C}$ yr BP, corresponds to $\mathrm{mm}$-scale layers consisting of authigenically precipitated aragonite. The base of the aragonite marks the onset of the marine Unit II (sapropel). Inorganic aragonite precipitation in the Black Sea is characteristic for the base of Unit II. The thickness of the aragonite layer depends on the sedimen- 


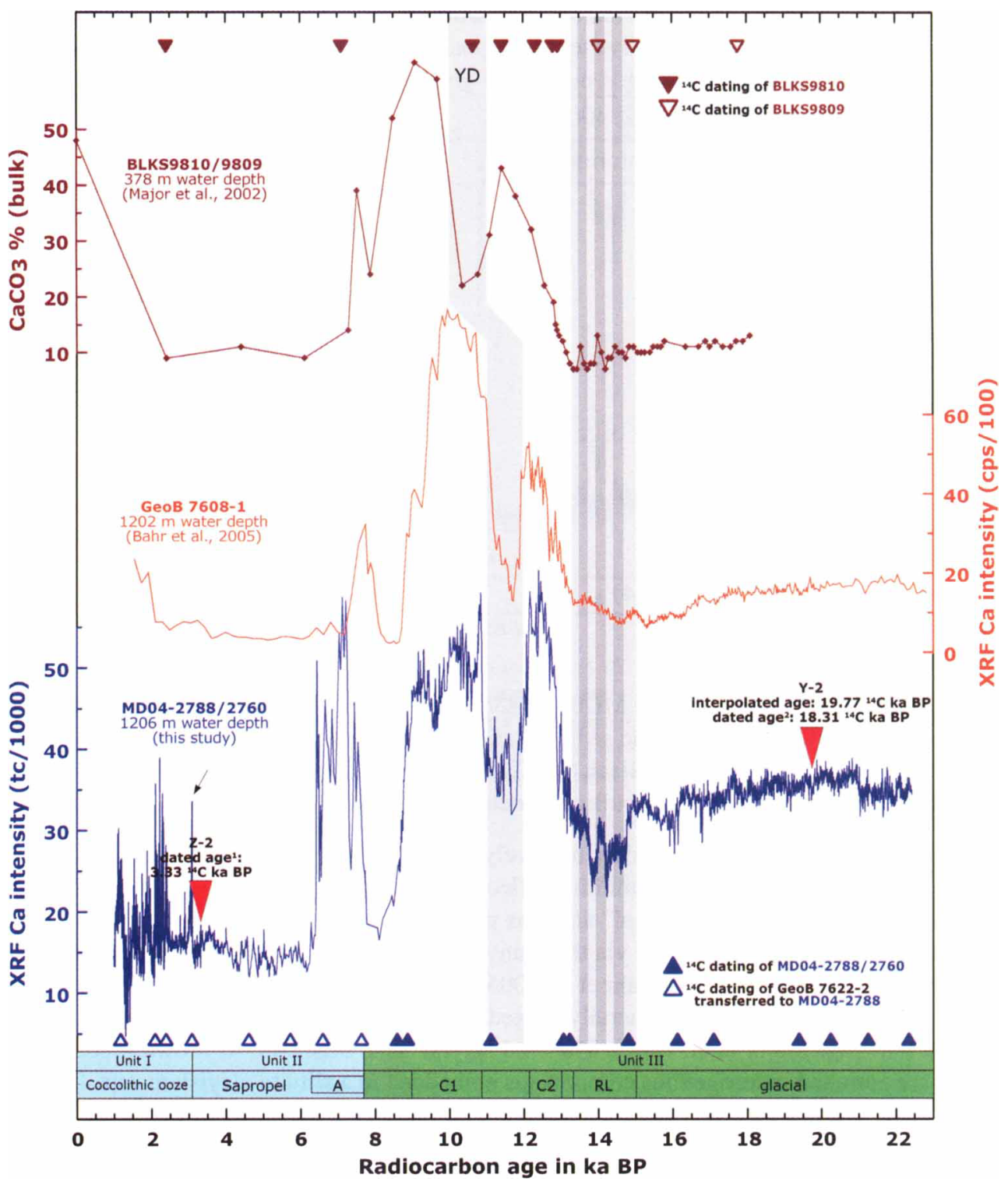

Figure 5 Juxtaposition of the Black Sea carbonate content/Ca intensity records (NS transect) showing a good agreement until $13{ }^{14} \mathrm{C}$ kyr (the "red layers" interval is indicated by light and dark gray bars) and a subsequent significant offset between the records from shallow and intermediate water depths. A maximum offset occurs during the Younger Dryas and is indicated by a light gray bar. AMS ${ }^{14} \mathrm{C}$ dating results are labeled with empty blue triangles for core GeoB 7622-2, filled blue triangles for MD04-2788/2760, filled red triangles for BLKS9810, and empty red triangles for BLKS9809. The dated age of the Z-2 Minoan Ash is given according to the AMS ${ }^{14} \mathrm{C}$ dating of Friedrich et al. (2006). The dated age of the Y-2 tephra is given according to the AMS ${ }^{14} \mathrm{C}$ dating of Pichler and Friedrich (1976) and Eriksen et al. (1999). The age of the Y-2 Cape Riva tephra is marked according to the linear interpolation between the 2 neighboring ${ }^{14} \mathrm{C}$ dates. The legend bar shows the major stratigraphic units including the "red layers" $(\mathrm{RL})$ and carbonate peaks $(\mathrm{Cl}, \mathrm{C} 2)$ in the lacustrine unit, and the aragonite peak (A) and the sapropel and coccolith ooze in the marine units. The nomenclature for the lacustrine peaks is after Major et al. (2002). Please note the legend bar refers to the stratigraphy of MD04-2788/2760. The small black arrow indicates the first appearance of E. huxleyi in the Black Sea. 


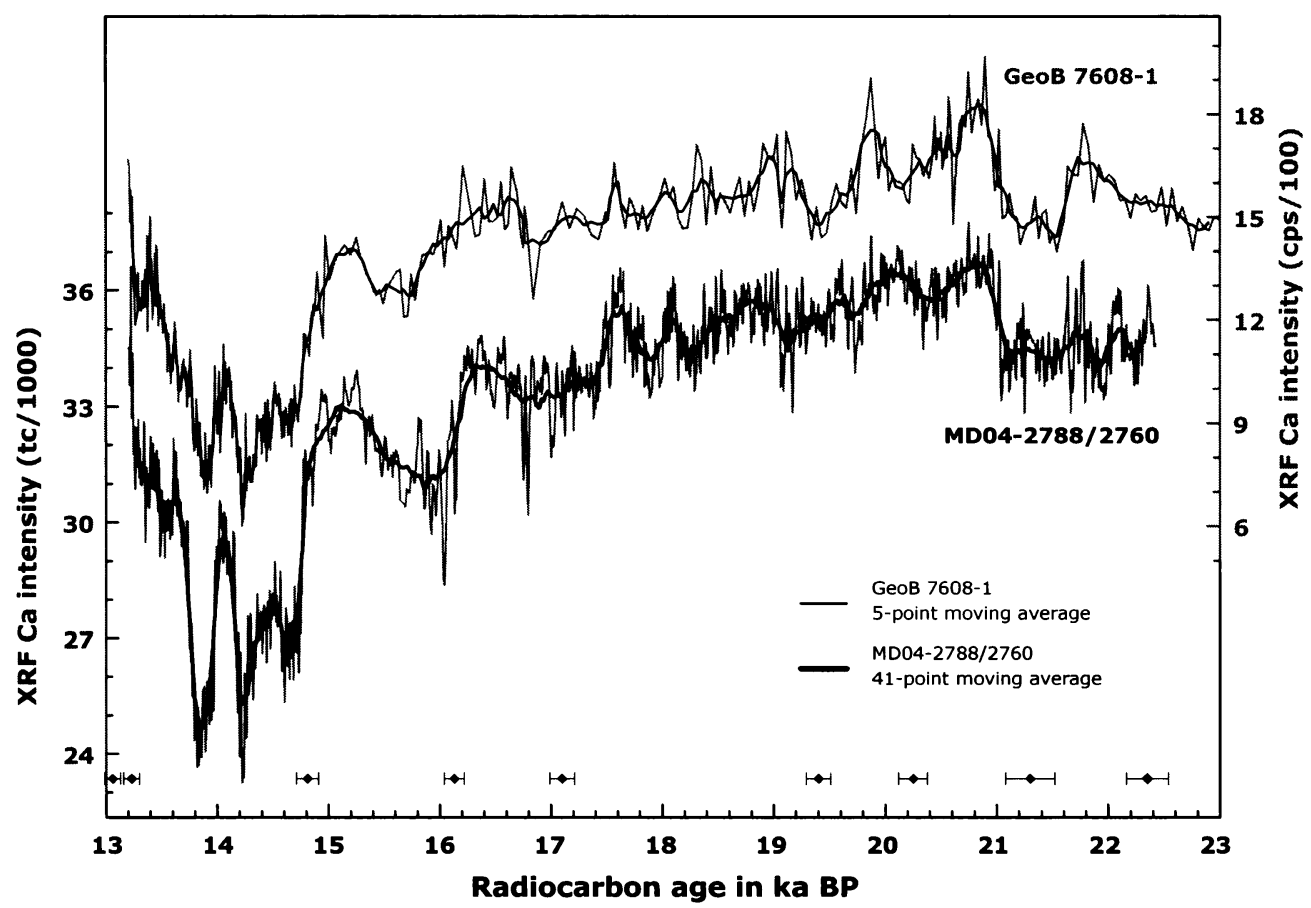

Figure 6 The XRF Ca intensity of the MD042788/2760 plotted on the ${ }^{14} \mathrm{C}$ timescale. The XRF Ca intensity of GeoB 7608-1 was tuned to the MD04-2788/2760 signal. The diamonds indicate AMS ${ }^{14} \mathrm{C}$ dating ( \pm dating error) of MD042788/2760. For GeoB 7608-1, the thin line represents the original data and the bold line represents a 5-point moving average. For the MD04-2788/2760, the thin line represents a 3-point moving average and the bold line a 41point moving average. The 2 cores were measured using different XRF core scanners, providing counts per second (cps) for GeoB 7608-1 and total counts (tc) for MD04-2788/1760.

tation rate and can vary significantly from a few $\mathrm{mm}$ to several $\mathrm{cm}$ (Ross and Degens 1974). The aragonite peak in the marine part of our record is related neither to the $\mathrm{Ca}$ maximum at $7520{ }^{14} \mathrm{C} \mathrm{yr}$ BP described by Major et al. (2002) from the lacustrine Unit III, nor to the Ca maximum at $\sim 7600$ ${ }^{14} \mathrm{C}$ yr BP described by Bahr et al. (2005), also from the Unit III (Figure 5). The separate carbonate peak as described from core BLSK9810 can be either an artifact (it is represented by a single measurement only) or a continuation of the carbonate peak $\mathrm{Cl}$ (C Major, personal communication, 2005), which is part of the basin-wide sedimentation pattern. Similarly, the Ca peak in GeoB 76081 most probably is detached from the carbonate peak $\mathrm{C} 1$ due to the dilution by siliciclastic material (A Bahr, personal communication, 2007).

Ca values, which are very low in marine Unit II (sapropel), increase significantly in Unit I. This increase is related to the occurrence of coccolith-rich layers. The single Ca peak at $\sim 3080{ }^{14} \mathrm{C} \mathrm{yr}$ indicates the first invasion of Emiliania huxleyi into the Black Sea, and marks the transition between Unit I and Unit II.

\section{DISCUSSION}

\section{Reservoir Age Variations}

The new ${ }^{14} \mathrm{C}$ ages, the presence of volcanic ash layers, and basin-wide sedimentological patterns suggest a significant and variable reservoir age for the late-glacial Black Sea. The identification of 
the Y-2 tephra for the first time in the Black Sea sediments, turned out to be essential for the estimation of the water reservoir ages in the glacial. By definition, the reservoir age represents the difference between the ${ }^{14} \mathrm{C}$ age of a marine/lacustrine sample and the ${ }^{14} \mathrm{C}$ age of a contemporaneous atmospheric sample. In core MD04-2788/2760, the Y-2 tephra is located between $2{ }^{14} \mathrm{C}$ dates. The linear interpolation between these 2 dates yields an age of $\sim 19,760{ }^{14} \mathrm{C} \mathrm{yr}$ for the tephra layer, which is $1450{ }^{14} \mathrm{C}$ yr older than the mean value of the reported $\mathrm{Y}-2$ terrestrial ages $\left(18,310{ }^{14} \mathrm{C} \mathrm{yr} \mathrm{BP}\right)$ (Table 3, Figure 4a).

Considering the original Cape Riva dating series (Pichler and Friedrich 1976; Eriksen et al. 1990), the end members of the reservoir age estimate are $1720{ }^{14} \mathrm{C}$ yr and $890{ }^{14} \mathrm{C}$ yr (Figure 4a) and the average reservoir age error is $\sim 400{ }^{14} \mathrm{C}$ yr (Table 3). Another indication that a reservoir correction becomes necessary is that the $\mathrm{Ca}$ minimum at $12,000-11,000{ }^{14} \mathrm{C} \mathrm{yr} \mathrm{BP}$, most probably representing the Younger Dryas (YD) cold interval (Major et al. 2002), is about $\sim 1000{ }^{14} \mathrm{C}$ yr older than the commonly assigned age for the YD (e.g. Hughen et al. 2000). Thus, the reservoir age seems to decrease from about $1450{ }^{14} \mathrm{C}$ yr close to the Last Glacial Maximum (LGM) to $\sim 1000{ }^{14} \mathrm{C}$ yr during the YD. However, in the interval between $\sim 15,000$ and $13,500{ }^{14} \mathrm{C}$ yr BP, the "red layers" interval, our record is in good agreement with the northwestern Black Sea record of Major et al. (2002) that was not corrected for any reservoir effect. According to the published $\delta^{18} \mathrm{O}$ data (Bahr et al. 2006), the Black Sea was in hydrological steady state during the glacial. Therefore, it is reasonable to assume a constant reservoir age over that time. The MD04-2788/2760 record suggests a subsequent reservoir age decrease towards the YD period to $\sim 1000{ }^{14} \mathrm{C}$ yr that starts at $\sim 13,000{ }^{14} \mathrm{C} \mathrm{yr} \mathrm{BP}$ and continues until the end of the lacustrine unit (Figure 5). This shift from 1450 to $\sim 1000{ }^{14} \mathrm{C}$ yr for the intermediate water reservoir age takes place within, or shortly after, the deposition of the "red layers." At the same time, the reservoir age of the upper water column reaches a value close to $0 \mathrm{yr}$ (Major et al. 2002; Bahr et al. 2005).

Additional support for the divergent trends in the reservoir ages of the different water masses comes from the observation of a temperature-dependent stratification of the Black Sea basin that started at $\sim 13,000{ }^{14} \mathrm{C}$ kyr BP and continued until the end of the lacustrine phase (Bahr et al. 2006).

The good agreement between the intermediate and upper water column records until $13,500{ }^{14} \mathrm{C} \mathrm{yr}$ BP (Figure 5) suggests that either: 1) there were no age differences at all and the reservoir age of the whole water column was $\sim 1450{ }^{14} \mathrm{C}$ yr; or 2) that the age of the upper water column and intermediate water were varying in the same way. To constrain our calibrated stratigraphy, we tested 2 hypotheses. A simple model assumes changes in the reservoir age only after the deposition of the "red layers" (at 13,500 ${ }^{14} \mathrm{C}$ yr BP), but divergent for the upper water column and the intermediate water (change to $0{ }^{14} \mathrm{C}$ yr for upper water column and to $1000{ }^{14} \mathrm{C}$ yr for intermediate water) (Figure 7, thin solid lines). A more complex model includes 2 changes of reservoir age: a first parallel change at the onset of the "red layer" deposition (at $\sim 15,000{ }^{14} \mathrm{C} \mathrm{yr} \mathrm{BP}$ ) to $1000{ }^{14} \mathrm{C}$ yr reservoir age; and a second divergent change after the "red layers" (after 13,500 ${ }^{14} \mathrm{C}$ yr BP) to $0{ }^{14} \mathrm{C}$ yr reservoir age for the upper water column and to $900{ }^{14} \mathrm{C}$ yr for the intermediate water (Figure 7, dashed lines). After calibration of the corrected ${ }^{14} \mathrm{C}$ dates, we compared the results of our models with the GISP2 ice core chronology (Grootes and Stuiver 1997). The first simple model shows a $\sim 350$-yr offset for the beginning of the Bølling-Allerød (B-A) and a 150-yr offset for the Younger Dryas (YD). The second complex model provides more satisfactory results, producing a $\sim 200$-yr offset for the beginning of the B-A and a 0 -yr offset for the YD (see Table 3). Based on the observations available for different water depths, we developed a rough model of estimated temporal changes in the Black Sea reservoir ages (Figure 7, Table 3). 


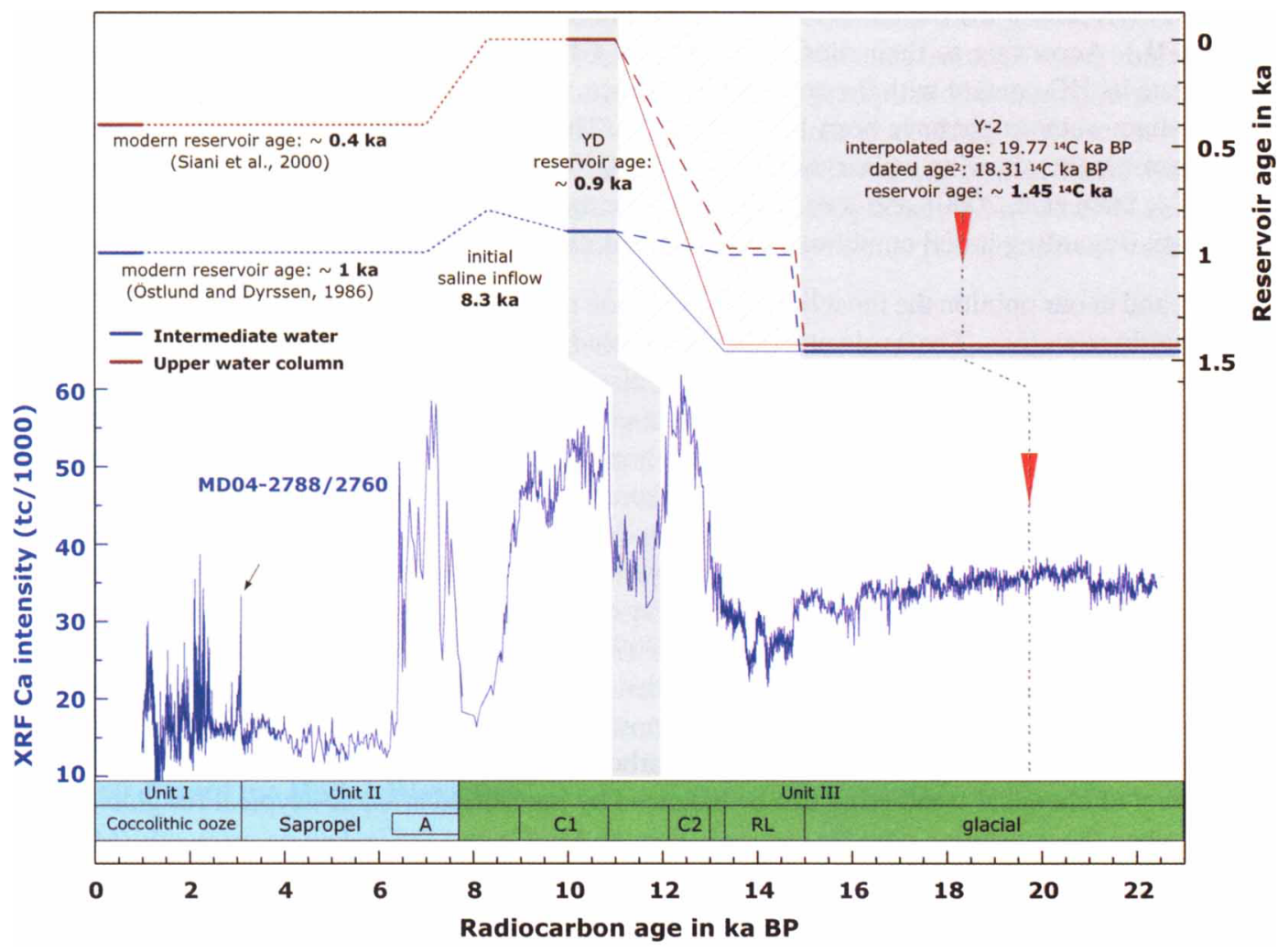

Figure 7 Model of temporal changes in the reservoir age of the Black Sea at different water depths juxtaposed with the MD04-2788/2760 XRF Ca intensity record. Blue lines represent the intermediate water and red lines the upper water column. Bold solid lines show the evolution of the reservoir ages based on observation. Between 15 and $11{ }^{14} \mathrm{C}$ kyr $\mathrm{BP}$, thin solid lines show the possible evolution of the reservoir ages following a simple model, while dashed lines show the evolution of the reservoir ages suggested by a more complex model (see section "Reservoir Age Variations"). Dotted lines represent the possible evolution of the reservoir age after $10{ }^{14} \mathrm{C}$ kyr BP. The age of the Y-2 Cape Riva tephra in MD04-2788/2760 is marked according to the linear interpolation between neighboring ${ }^{14} \mathrm{C}$ dates. The legend bar is the same as in Figure 5. The small black arrow indicates the first appearance of E. huxleyi.

\section{Source of the Age Offset}

The proposed reservoir age of $1450{ }^{14} \mathrm{C}$ yr for a presumably well-mixed water body in the glacial Black Sea is unexpected and requires some explanation. The contamination of samples by older carbonates is rather unlikely due to a careful inspection and cleaning of the dating samples. The location of the core MD04-2788/2760 was intentionally chosen on an isolated bathymetric high in order to avoid potential turbidite tracks. The sampled material showed no signs of reworking and all dating results appear in stratigraphical order. Finally, dating different material from the same interval yielded reproducible results (Table 3 ).

Another explanation for the large age offsets involves a potential temperature-dependent stratification of the basin, undetectable in the $\delta^{18} \mathrm{O}$ record. If this had been the case, the temperature signal might have been compensated by factors such as salinity, and changed $\delta^{18} \mathrm{O}$ of atmospheric precipitation (Bahr et al. 2006). Murray et al. (1991) presented a similar scenario for the marine Black Sea. Their ventilation box model implied that "old" deep water was upwelled to the surface, and subsequently cooled and removed from atmospheric contact to form a cold intermediate layer. Murray et 
al. (1991) referred to the depths between $25-100 \mathrm{~m}$ below the sea surface as the cold intermediate layer (CIL). According to their model, the time of CIL formation was too short for the water to equilibrate its ${ }^{14} \mathrm{C}$ content with the atmosphere. Hence, due to the depletion of ${ }^{14} \mathrm{C}$, both surface and intermediate water might have been $1400{ }^{14} \mathrm{C}$ yr old. This model, however, contradicts the results of ${ }^{14} \mathrm{C}$ measurements showing a reservoir effect of $\sim 400{ }^{14} \mathrm{C}$ yr in the recent Black Sea (Jones and Gagnon 1994; Siani et al. 2000), and was applied only for the marine Black Sea connected with the Mediterranean (regarding initial conditions and inflow of deep Mediterranean water).

A third, and in our opinion the most likely, explanation is the presence of an "apparent" reservoir age due to hardwater effect. The hardwater effect has already been proposed by Ross and Degens (1974) and Top and Clarke (1983) in order to resolve discrepancies between results of different dating methods applied to the Black Sea water and sediments. In the case of the hardwater effect, ${ }^{14} \mathrm{C}$ ages that are apparently "too old" are the result of the admixture of older "dead" carbon originating from the dissolution of old, radioactively "dead" carbonates. Potential sources of dissolved carbon are numerous in the Black Sea region. Old $\mathrm{CaCO}_{3}$-bearing rocks like limestones, marlstones, and sandy-carbonate flysch series are abundant all over the Black Sea drainage area. The Danube itself, which contributes $40 \%$ to the total Black Sea river runoff, drains through the Alpine domain dominated by old carbonatic rocks. Today, more than $70 \%$ of $\mathrm{CaCO}_{3}$ brought into the Black Sea by rivers is carried in solution (Strakhov 1951); however, this might have been different in the glacial. During cold periods, physical weathering is more pronounced than chemical weathering, and this may affect the amount of DIC (dissolved inorganic carbon) transported by rivers. Nevertheless, a weakened effect of chemical weathering can be balanced by intensified erosion-typical for glacial conditions when the vegetation cover is reduced. Though $\mathrm{Mg} / \mathrm{Ca}$ and $\mathrm{Sr} / \mathrm{Ca}$ data on ostracods (Major et al. 2006; Bahr et al. 2008) point to a rather low alkalinity of the glacial Black Sea water, the possibility of the hardwater effect is not eliminated. For example, Hajdas et al. (1995) reported the hardwater effect in the softwater body of Lake Holzmaar (Eifel, Germany).

\section{Timing and Mechanism of the Reservoir Age Decrease}

Assuming a hardwater effect as the reason for the age offset in the glacial calls for a mechanism to reduce this offset, at the latest at the start of the Allerød. A process is required to explain the reduction of the reservoir effect for the upper water column from $\sim 1450{ }^{14} \mathrm{C} \mathrm{yr}$ to nearly $0 \mathrm{yr}$ (or at least less than $900{ }^{14} \mathrm{C}$ yr) within a fairly short time interval. The comparison of our data with the upper water column records of Bahr et al. (2005) and Major et al. (2002) limits the decrease in reservoir ages to the time interval between $\sim 15,000$ and $\sim 13,000{ }^{14} \mathrm{C}$ yr BP. During this time span, 2 significant events contributed to the depositional history of the Black Sea: the "red layer" deposition (from $\sim 14,800$ to $\sim 13,500{ }^{14} \mathrm{C}$ yr BP) and an interval of widespread inorganic carbonate precipitation (commencing at $\sim 13,000{ }^{14} \mathrm{C}$ yr BP).

The "red layer" deposition involves an important inflow of glacial meltwater (Bahr et al. 2005). It is conceivable that this inflow added "younger" (in terms of ${ }^{14} \mathrm{C}$ content) water and diluted the hardwater effect "renewing" the Black Sea water. Indeed, significant meltwater pulses are observed in the $\delta^{18} \mathrm{O}$ ostracod record from core GeoB 7608-1 from $1202 \mathrm{~m}$ water depth (Bahr et al. 2006), indicating that the meltwater signal was transported deeper into the basin. This may explain why the reservoir age was changing parallel for the whole water column until $\sim 13,500{ }^{14} \mathrm{C}$ yr BP (Figure 7).

During the glacial period, exposed carbonate-rich bedrocks provided carbonate-rich sediments as a potential source of DIC. With the postglacial climate amelioration, the vegetation cover and soil formation in the Black Sea drainage basins probably played an important role in the reduction of the "old" carbon input. Karrow and Anderson (1975) describe a similar example from proglacial lakes 
in Canada. Besides the change in the "old" carbon supply, the decrease in the apparent reservoir age may involve additional processes such as the precipitation of carbonates from the water column that are enriched in the lighter carbon isotopes. Inorganic carbonate precipitation occurred in wide parts of the Black Sea basin during the Allerød. The $\delta^{13} \mathrm{C}$ record of Bahr et al. (2005) shows that the high amounts of inorganically precipitated calcite at the onset of Allerød were most likely linked to increased phytoplankton activity. Photosynthetic utilization of $\mathrm{CO}_{2}$ dissolved in water is known to induce supersaturation with respect to calcite and can lead to authigenic precipitation of carbonates (Kelts and Hsü 1978).

Since the reservoir age reduction takes place at the same time, it seems plausible that these processes are related. Such carbonate formation decreases the amount of DIC in the water (Zeebe and WolfGladrow 2001:74-83), depleting the dissolved carbon pool and potentially reducing the hardwater effect. To what degree the carbonate formation itself can account for a decrease in the reservoir age or what other biological processes are involved remains unclear. Both phytoplankton activity and authigenic calcite precipitation are taking place in the surface waters, affecting the age of the surface waters first. Subsequent winter convection and deep water formation (Bahr et al. 2006) could have introduced the surface signal into intermediate depths. Such a scenario would explain our observations after 13,000 ${ }^{14} \mathrm{C}$ yr BP (Figure 7) but also for the onset of the Holocene (Figure 7). This period is also characterized by authigenic calcite precipitation ( $\mathrm{Cl} \mathrm{Ca} \mathrm{peak)} \mathrm{and} \mathrm{a} \mathrm{re-advance} \mathrm{of} \mathrm{the} \mathrm{vege-}$ tation in the Eastern Mediterranean region (e.g. Zonneveld 1996; Robinson et al. 2006).

\section{Reservoir Age of the Marine Black Sea}

The limitation of the glacial reservoir age reconstruction consists in an inability to test our hypothesis, since the reservoir age of the recent marine Black Sea does not constitute an analog for the reservoir age of its lacustrine precursor. Observations and models valid for the marine Black Sea are inaccurate for reconstructing conditions over the Black "Lake," which had a significantly different hydrology as a closed basin without any connection to the Mediterranean Sea. Reservoir ages directly after the reconnection with the Mediterranean ( $\sim 8300{ }^{14} \mathrm{C} \mathrm{yr} \mathrm{BP}$, Bahr et al. 2006) must have been derived from the previous Black "Lake" state, as a result of the mixture of the "old" deep and intermediate waters, "young" upper column and surface waters, and inflowing saline Mediterranean water. After establishing the modern 2-layer flow and permanent stratification, the Black "Lake" hydrology was replaced by the recent marine Black Sea state. The total exchange time for the Black Sea water after reconnection was estimated to be $\sim 2000$ yr (Boudreau and Leblond 1989). This value fits well with the measured reservoir age of recent deep/bottom water (Östlund and Dyrssen 1986; Jones and Gagnon 1994). Recent AMS ${ }^{14} \mathrm{C}$ measurements on DIC in water samples show that deep/bottom water has a residence time of $\sim 2000{ }^{14} \mathrm{C}$ yr and in intermediate water $\sim 1400{ }^{14} \mathrm{C} \mathrm{yr}$, while the reservoir age of surface water is $\sim 400{ }^{14} \mathrm{C} \mathrm{yr}$, close to the mean global ocean reservoir age. As mentioned previously, rivers drain huge amounts of dissolved carbonates into the Black Sea. Hence, the hardwater effect cannot be excluded as a factor causing an apparent reservoir age also today. In contrast to the glacial conditions, however, the recent permanent stratification and isolation of the intermediate and deep waters from atmospheric $\mathrm{CO}_{2}$ favor not an apparent age but rather a real reservoir age.

\section{CONCLUSIONS}

During the glacial, we conclude that there was no offset between the age of the shallow and intermediate water of the Black Sea basin. As shown by ${ }^{14} \mathrm{C}$ measurements combined with tephrochronology, the Black Sea water was characterized by a uniform apparent age of $\sim 1450{ }^{14} \mathrm{C}$ yr that was 
primarily caused by the hardwater effect. An initial reduction of the reservoir age probably happened during the deglaciation due to the diluting effects of inflowing meltwaters, and might have shifted the apparent age of both the intermediate water and upper water column to $\sim 1000{ }^{14} \mathrm{C}$ yr. Later, with the onset of the Allerød, the reservoir age started to decrease divergently for the upper water column and the intermediate water. The second decrease was coincident with the precipitation of inorganic carbonates triggered by intense phytoplankton activity, both suggesting a biologically triggered reduction of the hardwater effect in the surface/upper water column. Additional changes in the vegetation cover and postglacial soil development in the drainage areas of the Black Sea inhibited an intense erosion of carbonatic bedrocks reducing the "old" carbon supply. During the Younger Dryas, the age of the upper water column was close to $0 \mathrm{yr}$, while the intermediate water was about $900{ }^{14} \mathrm{C}$ yr older. The recent reservoir age of the Black Sea waters was established after the reconnection with the Mediterranean Sea-the result of processes clearly different from those of the closed, glacial Black "Lake” basin.

\section{ACKNOWLEDGMENTS}

We thank the captain and crew of the R/V Marion Dufresne for their efficient support during the ASSEMBLAGE I cruise and the IPEV for logistic support (R/V Marion Dufresne). We also thank the 2 anonymous reviewers whose comments helped to improve the manuscript. This research was sponsored by Comer Science and Education Foundation (CS \& EF).

\section{REFERENCES}

Algan O, Gökaşan E, Gazioğlu C, Yücel ZY, Alpar B, Güneysu C, Kirci E, Demýrel S, Sari E, Ongan D. 2002. A high-resolution seismic study in Sakarya Delta and Submarine Canyon, southern Black Sea shelf. Continental Shelf Research 22(10):1511-27.

Bahr A, Lamy F, Arz H, Kuhlmann H, Wefer G. 2005. Late glacial to Holocene climate and sedimentation history in the NW Black Sea. Marine Geology 214(4): 309-22.

Bahr A, Arz HW, Lamy F, Wefer G. 2006. Late glacial to Holocene paleoenvironmental evolution of the Black Sea, reconstructed with stable oxygen isotope records obtained on ostracod shells. Earth and Planetary Science Letters 241(3-4):863-75.

Bahr A, Lamy F, Arz HW, Major C, Kwiecien O, Wefer G. 2008. Abrupt changes of temperature and water chemistry in the late Pleistocene and early Holocene Black Sea. Geochemistry, Geophysics, Geosystems 9: Q01004, doi: 10.1029/2007GC001683.

Boudreau BP, Leblond PH. 1989. A simple evolutionary model for water and salt in the Black Sea. Paleoceanography 4(2): 157-66.

Crusius J, Anderson RF. 1992. Inconsistencies in accumulation rates of Black Sea sediments inferred from records of laminae and ${ }^{210} \mathrm{~Pb}$. Paleoceanography $7(2)$ : 215-27.

Degens ET, Michaelis W, Garassi C, Mopper K, Kempe S, Ittekkot VA. 1980. Warven-Chronologie und frühdiagenetische Umsetzungen organischer Substanzen holozäner Sedimente des Schwarzen Meeres. Neues Jahrbuch für Geologie und Paläontologie Monats- hefte 2:65-86. In German.

Deuser WG. 1972. Late-Pleistocene and Holocene history of the Black Sea as indicated by stable-isotope studies. Journal of Geophysical Research 77(6): 1071-7.

Eriksen U, Friedrich WL, Buchardt B, Tauber H, Thomsen MS. 1990. The Stronghyle caldera: geological, palaentological and stable isotope evidence from radiocarbon-dated stromatolites from Santorini. In: Hardy DA, Keller J, Galanopoulos VP, Flemming NC, Druitt TH, editors. Thera and the Aegean World III. Volume Two: Earth Sciences. Proceedings of the Third International Congress, Santorini, Greece, 3-9 September 1989. London: The Thera Foundation. p 139-50.

Federman AN, Carey SN. 1980. Electron microprobe correlation of tephra layers from Eastern Mediterranean abyssal sediments and the Island of Santorini. Quaternary Research 13(2):160-71.

Friedrich WL, Kromer B, Friedrich M, Heinemeier J, Pfeiffer T, Talamo S. 2006. Santorini eruption radiocarbon dated to 1627-1600 B.C. Science 312(5773): 548.

Grootes PM, Stuiver M. 1997. Oxygen 18/16 variability in Greenland snow and ice with $10^{-3}$ - to $10^{5}$-year time resolution. Journal of Geophysical Research 102(C12):26,455-70.

Guichard F, Carey S, Arthur MA, Sigurdsson H, Arnold M. 1993. Tephra from the Minoan eruption of Santorini in sediments of the Black Sea. Nature 363(6430):610-2. 
Hajdas I, Zolitschka B, Ivy-Ochs SD, Beer J, Bonani G, Leroy SAG, Negendank JW, Ramrath M, Suter M. 1995. AMS radiocarbon dating of annually laminated sediments from lake Holzmaar, Germany. Quaternary Science Reviews 14(2):137-43.

Hammer CU, Clausen HB, Friedrich WL, Tauber H. 1987. The Minoan eruption of Santorini in Greece dated to 1645 BC? Nature 328(6130):517-9.

Hay BJ, Honjo S, Kempe S, Ittekkot VA, Degens ET, Konuk T, Izdar E. 1990. Interannual variability in particle flux in the southwestern Black Sea. Deep-Sea Research A 37(6):911-28.

Hughen KA, Southon JR, Lehman SJ, Overpeck JT. 2000. Synchronous radiocarbon and climate shifts during the last deglaciation. Science 290(5498): 19514.

Jansen JHF, Van der Gaast SJ, Koster B, Vaars AJ. 1998. CORTEX, a shipboard XRF-scanner for element analyses in split sediment cores. Marine Geology 151(1-4):143-53.

Jones GA. 1991. Constraining the initiation and evolution of anoxia in the Black Sea by AMS radiocarbon dating. Radiocarbon 33(2):211-2.

Jones GA, Gagnon AR. 1994. Radiocarbon chronology of Black Sea sediments. Deep-Sea Research I 41(3): 531-57.

Karrow PF, Anderson TW. 1975. Palynological studies of lake sediments profiles from southwestern New Brunswick: discussion. Canadian Journal of Earth Sciences 12:1808-12.

Keller J, Ryan WBF, Ninkovich D, Altherr R. 1978. Explosive volcanic activity in the Mediterranean over the past 200,000 yr as recorded in deep-sea sediments. Geological Society of America Bulletin 89(4):591604.

Kelts K, Hsü KJ. 1978. Freshwater carbonate sedimentation. In: Lerman A, editor. Lakes: Chemistry, Geology, Physics. New York: Springer-Verlag. p 295-323.

Lamy F, Arz HW, Bond G, Bahr A, Pätzold J. 2006. Multicentennial-scale hydrological changes in the Black Sea and northern Red Sea during the Holocene and the Arctic/North Atlantic Oscillation. Paleoceanography 21: PA1008, doi: 10.1029/2005PA001184.

Major C, Ryan W, Lericolais G, Hajdas I. 2002. Constraints on Black Sea outflow to the Sea of Marmara during the last glacial-interglacial transition. Marine Geology 190(1-2):19-34.

Major CO, Goldstein SL, Ryan WBF, Lericolais G, Piotrowski AM, Hajdas I. 2006. The co-evolution of Black Sea level and composition through the last deglaciation and its paleoclimatic significance. Quaternary Science Reviews 25(17-18):2031-47.

Murray JW, Top Z, Özsoy E. 1991. Hydrographic properties and ventilation of the Black Sea. Deep-Sea Research 38 (Supplement 2):663-89.

Nadeau M-J, Schleicher M, Grootes PM, Erlenkeuser H, Gottdang A, Mous DJW, Sarnthein JM, Willkomm H. 1997. The Leibniz-Labor AMS facility at the
Christian-Albrechts University, Kiel, Germany. Nuclear Instruments and Methods in Physics Research B 123(1-4):22-30.

Östlund HG, Dyrssen D. 1986. Renewal rates of the Black Sea deep water. In: Proceedings of the Chemical and Physical Oceanography of the Black Sea. Göteborg, Sweden, 1986.

Pichler H, Friedrich W. 1976. Radiocarbon dates of Santorini volcanics. Nature 262(5567):373-4.

Reimer PJ, Baillie MGL, Bard E, Bayliss A, Beck JW, Bertrand CJH, Blackwell PG, Buck CE, Burr GS, Cutler KB, Damon PE, Edwards RL, Fairbanks RG, Friedrich M, Guilderson TP, Hogg AG, Hughen KA, Kromer B, McCormac G, Manning S, Bronk Ramsey C, Reimer RW, Remmele S, Southon JR, Stuiver M, Talamo S, Taylor FW, van der Plicht J, Weyhenmeyer CE. 2004. IntCal04 terrestrial radiocarbon age calibration, 0-26 cal kyr BP. Radiocarbon 46(3): 1029-58.

Robinson SA, Black S, Sellwood BW, Valdes PJ. 2006. A review of palaeoclimates and palaeoenvironments in the Levant and Eastern Mediterranean from 25,000 to 5000 years BP: setting the environmental background for the evolution of human civilisation. Quaternary Science Reviews 25(13-14):1517-41.

Röhl U, Abrams LJ. 2000. High-resolution, downhole, and nondestructive core measurements from sites 999 and 1001 in the Caribbean Sea: application to the late Paleocene thermal maximum. In: Leckies RM, Sigurdsson H, Acton GD, Draper G, editors. Proceedings of the Ocean Drilling Program Scientific Results 165: 191-203.

Ross DA, Degens ET, editors. 1974. The Black Sea: Geology, Chemistry, and Biology. Tulsa, Oklahoma, USA: American Association of Petroleum Geologists. $633 \mathrm{p}$.

Ross DA, Degens ET, MacIlvaine J. 1970. Black Sea: recent sedimentary history. Science 170(3954): 163-5.

Ryan WBF, Pitman III WC, Major CO, Shimkus K, Moskalenko V, Jones GA, Dimitrov P, Gorür N, Sakinç M, Yüce H. 1997. An abrupt drowning of the Black Sea shelf. Marine Geology 138(1-2):119-26.

Schrader H-J. 1979. Quaternary paleoclimatology of the Black Sea basin. Sedimentary Geology 23(1-4):16580.

Siani G, Paterne M, Arnold M, Bard E, Métivier B, Tisnerat N, Bassinot F. 2000. Radiocarbon reservoir ages in the Mediterranean Sea and Black Sea. Radiocarbon 42(2):271-80.

Strakhov JJ. 1951. Outline of carbonate accumulation in modern reservoirs. In: Schatskiy NS. Memorials to Academican A.D. Arcgangielskiy. Moscow: Izv. Akad. Nauk SSSR. p 487-567.

Stuiver M, Reimer PJ. 1993. Extended ${ }^{14} \mathrm{C}$ data base and revised CALIB $3.0{ }^{14} \mathrm{C}$ age calibration program. $R a$ diocarbon 35(1):215-30.

Stuiver M, Reimer PJ, Reimer RW. 2005. CALIB 5.0. [WWW program and documentation]. URL: http:// calib.qub.ac.uk/calib/. 
Sur HI, Özsoy E, Ilyin YP, Ünlüata Ü. 1996. Coastal/ deep ocean interactions in the Black Sea and their ecological/environmental impacts. Journal of Marine Systems 7(2-4):293-320.

Top Z, Clarke WB. 1983. Helium, neon and tritium in the Black Sea. Journal of Marine Research 41(1):1-17.

Vinci A. 1985. Distribution and chemical composition of tephra layers from Eastern Mediterranean abyssal sediments. Marine Geology 64(1-2):143-55.

Wulf S, Kraml M, Kuhn T, Schwarz M, Inthorn M, Keller J, Kuscu I, Halbach P. 2002. Marine tephra from the Cape Riva eruption (22 ka) of Santorini in the Sea of Marmara. Marine Geology 183(1-4):131-41.
Wulf S, Kraml M, Keller J. Forthcoming. Towards a detailed distal tephrostratigraphy in the Mediterranean: the last 20,000 yrs record of Lago Grande di Monticchio. Journal of Volcanology and Geothermal Research.

Zeebe RE, Wolf-Gladrow D, editors. 2001. $\mathrm{CO}_{2}$ in Seawater: Equilibrium, Kinetics, Isotopes. Amsterdam. Elsevier. 346 p.

Zonneveld KAF. 1996. Palaeoclimatic reconstruction of the last deglaciation (18-8 ka BP) in the Adriatic Sea region; a land-sea correlation based on palynological evidence. Palaeogeography, Palaeoclimatology, Palaeoecology 122(1-4):89-106. 